\title{
A Contrastive Study on Rhetoric in COVID-19-Related News Headlines from Native and Non-Native English Online Newspapers
}

\author{
JITSUDA LAONGPOL \\ English Liberal Arts Program, \\ Faculty of Humanities and Social Sciences, \\ Yala Rajabhat University, Thailand \\ jitsuda.l@yru.ac.th
}

\begin{abstract}
Rhetorical devices have been widely used in a variety of writing works including news headlines. These short messages are considered to be the first informative and persuasive product of news reports. This research aims to investigate what type of rhetoric was most frequently found in English news headlines and to compare the similarities and differences of the rhetorical aspects of the headlines taken from two major online news websites in England and Thailand. The 2-week corpus includes 594 coronavirus-related headlines: 351 headlines collected from the BBC and 243 from the Bangkok Post. All electronic news headlines are contrastively analysed based on Shams's (2013) and Picello's (2018) taxonomies. The findings reveal that there are twelve rhetorical devices found in these headlines. Alliteration noticeably marks the highest frequency among all rhetorical features, followed by metonymy, rhyme, depersonalization, rhetorical question, metaphor, hyperbole, pun and euphemism, cliché, allusion, and simile respectively. The combination of alliteration and metonymy is commonly found in news headline writing. However, allusion and simile are only found in the headlines from the Bangkok Post, but at very low frequencies. Furthermore, the metonymic uses in the headlines may reflect certain preferred ideologies of presenting coronavirus-related news between the two counterparts.
\end{abstract}

Keywords: rhetoric; news headlines; online news websites; native and non-native countries; COVID-19

\section{INTRODUCTION}

News is a part of people's daily lives. Most issues considered important to society are selected and communicated to the public. Picello (2018, p.124) explained that the word 'news' can mean both 'important or interesting recent happenings...' This is in line with the definition suggested by Reah $(2002$, p.4) that 'news' refers to 'information about recent events that are of interest to a sufficiently large group, or that may affect the lives of a sufficiently large group'. News is available through newspapers, television, radio and also online sources. With the progress of advanced technology, the internet has also enabled readers or news consumers to get global news information by just watching what is happening worldwide on screen from various news websites. These convenient sources have contributed to changing people's lifestyles and internet users' decision to get their news online instead of from printed newspapers.People can easily get updatesregarding any interesting news especially important information which can directly impact their lives.

In November 2019, the big news that sparked public attention was about a novel Sarslike virus. The disease firstly threatened locals in the city of Wuhan in Hubei province, China. The unknown disease at that time was often referred to as the 'mystery pneumonia virus' and then 'new Chinese virus'. It was later known as the '2019 novel coronavirus' and was officially named 'COVID-19' by the World Health Organization (WHO). The severe respiratory illness, which has spread to nearly every country, has acutelyimpacted economy, employment, education, entertainment, and even people's lifestyles. The deadly disease has claimed more than two million lives and infected more than 100 million people worldwide according to the data last updated on March $10^{\text {th }}$, 2021 from the website 
https://www.worldometers.info/coronavirus/. Different measures as wearing face masks, working from home (WFH), banning mass gatherings, social distancing and lockdowns have been implemented in order to combat the fast-spreading coronavirus. This news has been reported continuously to the public through a variety of media channels including electronic news websites. Readers can follow the daily flow of the information about the infectious disease from short, concise, and persuasive messages, known as 'news headlines'.

According to Conboy (2007), headlines serve three functions: providing a brief summary of the main news, attracting attention, and providing an initial indicator of the content and style of the news to readers. Headlines immediately transmit the gist of a whole news story to readers who can then consider whether the content is newsworthy or worth reading. Electronic headlines are considered to be another news-reporting tool which can serve the public nowadays, as well as traditional headlines in printed newspapers. Saxena (2004) mentioned that the best headlines are characterised by the use of simple, specific, and concrete words. He added that an Internet headline is a signpost which can motivate readers to proceed to read a story or fail to capture their interest. As a result of this, these 'essential short messages' are specifically designed using linguistic and stylistic features in an attempt to sustain the news readers' ongoing curiosity and perception of intended meaning.

According to previous studies (Bonyadi\& Samuel, 2012; Farrokhi\&Nazemi, 2015; Magtira\& Bernardo, 2017; Zhou, 2017; Lamichhane, 2017; Winita\&Ermanto; 2018), the use of rhetorical devices in news headlines is one of the issues most researchers have been interested in researching. McGuigan (2007) proposed that the four main purposes of using rhetorical devices are to persuade, to inform, to express, and to entertain. He added that "The stylistic devices that you choose will have a powerful effect, one way or another, on the reception that your writing receives (2007, p. 3)". Furthermore, Shumin (2006), as cited in Magtira\& Bernardo (2017, p. 16), suggested that "Newspaper headlines frequently make use of rhetorical devices as an effective way to attract and impress the readers." Therefore, it can be assumed here that rhetorical devices are important tools that journalists can use to heighten the perception and stimulate the emotion of the audience. Various rhetorical devices are employed to achieve specific purposes and influence the popularity of the product, which is news. Rhetoric involves imaginative language such as hyperbole, personification, simile, metaphor, etc. which may not solely convey the meanings of individual words or phrases, but go beyond the literal meanings. The substitution of the name of one thing for that of another with which it is associated is a major characteristic of metonymy, commonly found in news headlines. Moreover, sound-related devices such as alliteration and rhyme are other tools which can effectively enhance the communication between headline writers and their readers.

\section{LITERATURE REVIEW}

Rhetoric is commonly found in speaking and writing. This is supported by Shams (2013, p. 146) who explained that "Rhetoric refers to persuasive writing or speaking used by people to manipulate the audience into agreeing with an idea, forming a belief, making a value judgment, or taking an action..." With respect to writing, authors include rhetoric in a range of writing, especially literature. Language is used in both imaginative and phonological forms. Persuasion is one of the three purposes of writing news headlines, as suggested by Shams; a writer creates a piece of writing by utilising rhetoric to convince and attract readers according to the way his work is written and displayed. van Dijk (1988) added that each type of rhetoric differs in function, providing alternate methods to make the text more persuasive. Rhyme or assonance can establish phonological operations, parallelisms can display syntactic operations, and comparisons or metaphors can represent semantic operations. In addition, news reports may 
contain hyperboles (overstatements, exaggerations), understatements, contrast, or climax. This can contribute to a tighter organisation of news and possibly lead to better remembrance by readers (van Dijk, 1988). Consequently, rhetoric has become a preferred and powerful tool widely employed in other kinds of writing, including news headlines.

In regard to the findings of Bonyadi\& Samuel (2012), the textual data taken from the electronic versions of the Tehran Times, the Islamic Republic of Iran's first English daily newspaper, and the New York Times, an English online newspaper of the United States of America, indicated twelve rhetorical features appearing in the forty selected editorial headlines. Metonymy was the most dominant rhetorical device occurring in both sets of data. There were also allusion, neologism, rhetorical question, metonymy, antithesis, parallelism, alliteration, consonance, irony, quoting out of context, testimonial, and pun. Similarities and differences in the domain of rhetorical types occurred. Rhetorical question, metonymy, parallelism, alliteration, and consonance were found on both news websites. However, quoting out of context, testimonial, and pun were only found in the online news website of Iran while allusion, neologism, antithesis, and irony were solely used in the American news website in this study.

Using the analysis framework of Bonyadi\& Samuel (2012), Magtira\& Bernardo (2017) pointed out that newspaper editorial headlines in two newspapers, namely The New York Times and Philippine Daily Inquirer, contained fourteen rhetorical devices. Metonymy was still the main linguistic technique seen in the American and the Filipino print media. Some headlines shared the same rhetorical types between the two newspapers; they were parallelism, alliteration, and idiom. Four more features, i.e., rhetorical question, metonymy, pun, and oxymoron, were other features employed in The New York Times while hyperbole, simile, irony, sarcasm, onomatopoeia, consonance, and epithet were seven other aspects found in the Philippine Daily Inquirer.

In an effort to identify the use of rhetorical devices in English online news headlines, Monsefi\&Mahadi (2016) found that metonymy was most often employed in the corpus of 100 selected English news headlines taken from the Euronews website, followed by ellipsis and personification, respectively. The researchers later published another related research paper on the rhetorical presentation of Persian news headlines gathered from the same news website. According to their findings (Monsefi\&Mahadi, 2017), metonymy was also found at the highest frequency, the second was personification, and then ellipsis.

Another study of rhetorical domains was conducted by Zhou (2017) in Thailand. The top six types of rhetoric found in fifty English daily news headlines from the Bangkok Post and The Nation were respectively metonymy, metaphor, alliteration, oxymoron, personification, and quotation. She pointed out that alliteration, consonance, assonance, and onomatopoeia represented sound effects.Metonymy, metaphor, and personification stimulated readers' imagination, and oxymoron, paradox, pun, irony, and rhetorical question might possibly arouse the readers' curiosity and interest.

With respect to the study of Maretha\&Kongthai (2017), 139 relevant online news headlines relating to a Gerwani-related issue, a debarred women's organisation in Indonesia's New Order regime, were collected from fourteen online news websites to analyse. The sources were the Jakarta Post, Jakarta Globe, the Guardian, the Diplomat, Aljazeera, The Conversation, News Mandala, The International People's Tribunal (IPT) 1965, Inside Indonesia, NYR Daily, Foreign Policy, Tempo, Green Left Weekly, and Pacific Media Center published from 1999-2016. Based on the content analysis, the results showed that the verbal rhetorical devices with the highest frequency were metonymy, followed by parallelism, alliteration, testimonial, rhetorical question, and antithesis, respectively, while irony and quotation out of context ranked the lowest in frequency.

Lamichhane (2017) carried out research to identify and analyse the stylistic features of newspaper headlines in terms of lexical, rhetorical, and syntactic features. Focusing only on 
the use of rhetorical devices, twenty English headlines from The Himalayan Times and the same number of headlines from The Kathmandu Post showed that alliteration was the most frequently used, followed by metaphor.

The above-mentioned review shows that there are a wide range of rhetorical aspects employed in news headlines. Nevertheless, metonymy frequently occurs as the most dominant tool in the presentation of headlines. The previous findings have thus led the researcher to be interested in investigating how rhetorical aspects are employed in English news headlines publicised on the news websites of an English-speaking country, England, and a non-native country, Thailand. In addition, the news about the global spread of the novel coronavirus, or COVID-19, is an innovative issue to study. It has attracted scholars as Tan et al. (2020) who publicized a series of research papers mainly relevant to linguistic aspects. Therefore, investigating how rhetorical devices are used in coronavirus-related news is also worth further study. These news headlines may yield certain interesting points of how language is used in mass media. The findings are expected to be significant to students of journalism and English. Also, English teachers might benefit by using news headlines as authentic teaching materials in their language classrooms.

\section{RESERCH OBJECTIVES}

1. To explore the most frequently used rhetorical device in English news headlines from the $B B C$ and the Bangkok Post websites

2. To compare the similarities and differences of rhetorical features used in online news headlines between the $B B C$ and the Bangkok Post

\section{ANALYTICAL FRAMEWORK}

According to her book Key Concepts of English Language and Linguistics: A coursebook for university students, Picello (2018) claimed that verbal rhetorical devices such as alliteration, metaphor, cliché, metonym, hyperbole, rhyme, allusion, pun, and ellipsis are the ones which appear most frequently in news headlines. Shams (2013, pp. 146-157) also suggested some more rhetorical categories in his book, Newspaper in the ELT Classroom: A Guide to the English Newspaper for ESL/EFL Students. They are simile, depersonalization, euphemism, derogation, and rhetorical question. All fourteen above-mentioned aspects were chosen to form the main guideline used in the contrastive analysis process of this study. The definitions of each rhetorical term and certain examples presented by Picello and Shams are described below:

Alliteration is the repetition of starting letters of words in a phrase or sentence at the beginning of two or more words and effectively creates a kind of affective rhythm.

Example: Clinton, CastoDuel Due

Spice Girls Feel the Fickle Finger of Fame

Football Fan Fury

Domestic Dissidents and Foreign Foes

Metaphor is the substitution of one idea for another.

Example: The attacks were a long-run economic depressant. ('The attacks' are compared to 'a long-run economic depressant')

Cliché is the use of well-worn phrases, ideas, metaphors, allusion and so on to generate recognition, quickly deploying meaning. 
Metonymy refers to a part of something used to represent it as a whole. It can be used as a reference to a whole organisation, institution, or country and is used to stand for the people who actually make a decision or perform an action.

Example: $\quad$ The Army wants to reinstitute the draft.

England won the World Cup.

The land belongs to the Crown.

We await words from the Throne.

Hyperbole is a rhetorical device which is used as a description of an event or action in strongly exaggerated and extravagant terms to emphasize, express emotions, etc. It is commonly employed in news, particularly to emphasize others' negative characteristics or actions.

Example:

a million thanks

White House Under Siege

Rhyme is an obviously poetic rhetorical device, referring to the identity of the final accented vowel and all the following sounds in two words. It can create a pleasant sound or musical effect.

Example: $\quad$ Clarke's Bummer for the Summer

DocKnocksFrocks In Flu Shocks

Allusion can make direct or indirect references to other ideas, places, people, or texts, generating an effect based around the pleasure of recognition.

Pun is a play on words alike or words that are nearly alike in sound but different in meaning.

Example: "all the fax about new technology"

Ellipsis is simply the omission of data, usually of what we take to be obvious. It is often written as a row of three dots.

Simile refers to a stated comparison between dissimilar objects or ideas defined as an idea, but the relationship between the ideas and objects is established explicitly through the use of certain words 'like' or 'as', etc.

Example: Immigrants are like an invading army.

Depersonalization in newspapers is used to influence the readers and manipulate the perception and impression of events in a specific direction. There is no sign of human agents who cause the events.

Example: $\quad$ Israeli Guns Kill 4-Month-Old Baby

(The agent can be'Soldiers')

Bombing Destroys Kabul's Historic Mosque

(The agent can be 'Military')

The use of euphemism in newspapers refers to an alternative expression for an idea considered taboo or inappropriate in which more socially or politely acceptable terms are used instead.

Derogation, on the other hand, represents derogatory terms, which are negatively charged words used to damage or take away from people's credit and reputation.

Rhetorical question is the use of a question which is not asked with the intention of receiving an answer, but instead is asked in order to lead readers into thinking in a specific way. 


\section{METHODOLOGY}

The total of 594 English online headlines, which included 351 headlines collected from the $B B C$ and 243 from the Bangkok Post, was taken to be the main corpus for analysis. The headlines relevant to COVID-19 were purposely adopted from the news website https://www.bbc.com/news/world of the $B B C$, which is a major news agency of an Englishspeaking country, England, and the site https://www.bangkokpost.com/news/world of the Bangkok Post, which is an online daily newspaper in Thailand.The criterion in selecting these two news websites as the resources was that they are well-known media with a variety of news items. The researcher focused only on the COVID-19 related headlines from the "World" section of both sites from April 5-18, 2020 because the international news stories varied widely in presenting the relevant global information in different perspectives. To confirm the relevance of the news in terms of coronavirus, the leads for each selected headline were also considered before choosing.

Based on the fourteen rhetorical aspects suggested by Shams (2013) and Picello (2018), alliteration, metaphor, cliché, metonymy, hyperbole, rhyme, allusion, pun, ellipsis, simile, depersonalization, euphemism, derogation, and rhetorical question were chosen as the main devices in analysing the two sets of data. The researcher carefully studied Shams's and Picello's terms, definitions and examples concerning the aforementioned rhetorical tools representing both figurative use of language and phonological presentation. All 594 headlines were analysed individually and the results were recorded. The final findings were later compared to highlight the similarities and differences of rhetoric used in the presentation of the same news between the two different online websites. Data was analysed and interpreted qualitatively. Percentages were calculated as statistical data according to the rhetorical devices found in the headlines to mark the frequency of each aspect, then presented in tables to describe the occurrences of each rhetorical form found in this study.

\section{FINGDINGS AND DISCUSSION}

Alliteration, metonymy, rhyme, depersonalization, rhetorical question, metaphor, hyperbole, pun, euphemism, cliché, allusion, and simile were found in the study. However, the two online newspapers were found to be different in terms of employing certain rhetorical devices. Allusion and simile were only found in the Bangkok Post website, but at very low frequencies. Alliteration was the most frequent, followed by metonymy and rhyme; ellipsis and derogation were not found in either of the two counterparts.

TABLE 1. Frequencies of Rhetorical Devices in English Online Headlines from the $B B C$ and the Bangkok Post News Websites

\begin{tabular}{|c|c|c|c|}
\hline No. & Rhetorical Devices & Frequency & $\%$ \\
\hline 1 & Alliteration & 246 & 40.66 \\
\hline 2 & Metonymy & 201 & 33.22 \\
\hline 3 & Rhyme & 53 & 8.76 \\
\hline 4 & Depersonalization & 30 & 4.95 \\
\hline 5 & Rhetorical Question & 22 & 3.63 \\
\hline 6 & Metaphor & 18 & 2.97 \\
\hline 7 & Hyperbole & 11 & 1.81 \\
\hline \multirow[t]{2}{*}{8} & Pun & 8 & 1.32 \\
\hline & Euphemism & 8 & 1.32 \\
\hline 9 & Cliché & 4 & 0.66 \\
\hline 10 & Allusion & 3 & 0.49 \\
\hline 11 & Simile & 1 & 0.16 \\
\hline \multirow[t]{2}{*}{12} & Ellipsis & 0 & 0 \\
\hline & Derogation & 0 & 0 \\
\hline Total & & 605 & 100 \\
\hline
\end{tabular}


Table 1 shows the results in which the frequency of alliteration $(40.66 \%)$ ranked significantly higher than other rhetorical aspects in the English COVID-19-related news headlines from the websites of the $B B C$ and the Bangkok Post. Metonymy (33.22\%) ranked second in number of occurrences, rhyme $(8.76 \%)$ came third, followed by depersonalization (4.95\%), rhetorical question (3.63\%), metaphor (2.97\%), hyperbole $(1.81 \%)$, pun and euphemism $(1.32 \%)$, cliché $(0.66 \%)$, allusion $(0.49 \%)$, and simile $(0.16 \%)$. Ellipsis and derogation were not found in the two sets of headlines.

Alliteration occurring at the highest frequency in the headlines was in line with the study conducted by Lamichhane (2017). However, this was different from the findings of Bonyadi \& Samuel (2012); Magtira \& Bernardo (2017); Monsefi \& Mahadi (2016, 2017); Zhou (2017); Maretha \& Kongthai (2017) that metonymy was found at the highest frequency.

One reason why alliteration ranked at the highest frequency in this study might be due to its specific characteristics. In general, alliteration makes use of the same initial letter sounds in nearby words to produce a musical effect on the individual perception and feeling of readers. Using this phonetic device to create a news headline catches the readers' attention. As supported by Bowden (2013), alliteration is frequently used in news headlines with the purpose of creating a consistent pattern that catches the mind's eye, or imagination, and focuses the audience's attention. Using alliteration is beneficial in presenting news, especially the information about the COVID-19 pandemic. The outbreak has led to a dramatic loss of human life worldwide. The long-term impact of the pandemic has varied from country to country. Catchy alliteration can also be used to emphasise a major message or phrase and fix it in the audience's mind (Bowden, 2013). Through using the technique of alliteration, the repetition of the starting letters could help the reader remember details regarding the ongoing situation of the disease infection surrounding them. Furthermore, Harris (2003, p. 127) pointed out that "alliteration adds not only a bit of music to your writing but an emphasis on ideas that will help your reader recall a key concept better." This can help the reader to get the gist of the news information as well as enjoy the beauty of literary writing. Alliteration is also employed in news headlines to promote news stories. As supported by Bowden (2013), this phonological device is sometimes used in advertising and business names to make them more memorable, exemplified by these two successful brands: Krispy Kreme and Coca-Cola. News headlines are also designed to be an appealing product and aim to attract readers with the use of the powerful sound tool of alliteration.

TABLE 2.Comparison of Rhetorical Devices in the BBC and the Bangkok Post

\begin{tabular}{|c|c|c|c|c|}
\hline \multirow[t]{2}{*}{ Rhetorical Devices } & \multicolumn{2}{|c|}{$B B C$} & \multicolumn{2}{|c|}{ Bangkok Post } \\
\hline & Frequency & $\%$ & Frequency & $\%$ \\
\hline Alliteration & 125 & 37.65 & 121 & 44.32 \\
\hline Metonymy & 122 & 36.74 & 79 & 28.93 \\
\hline Rhyme & 30 & 9.03 & 23 & 8.42 \\
\hline Rhetorical Question & 14 & 4.21 & 8 & 2.93 \\
\hline Depersonalization & 12 & 3.61 & 18 & 6.59 \\
\hline Hyperbole & 10 & 3.01 & 1 & 0.36 \\
\hline Metaphor & 9 & 2.71 & 9 & 3.29 \\
\hline Cliché & 3 & 0.90 & 1 & 0.36 \\
\hline Pun & 2 & 0.60 & 6 & 2.19 \\
\hline Euphemism & 5 & 1.50 & 3 & 1.09 \\
\hline Allusion & 0 & 0 & 3 & 1.09 \\
\hline Simile & 0 & 0 & 1 & 0.36 \\
\hline Ellipsis & 0 & 0 & 0 & 0 \\
\hline Derogation & 0 & 0 & 0 & 0 \\
\hline Total & 332 & 100 & 273 & 100 \\
\hline
\end{tabular}


As illustrated in Table 2, the top three rhetorical features of the English online news headlines from the two websites were the same: alliteration, metonymy, and rhyme. However, the occurrences of metonymy in the two news websites were significantly different in number. The frequency of metonymy in the $B B C$ was higher if compared to the number of occurrences in the Bangkok Post (36.74\% and $28.93 \%$ respectively.) In addition, allusion and simile were only found in the Bangkok Post, but at very low numbers (1.09\% and $0.36 \%$ respectively).

In this study, allusion was rarely found in the headlines. As Baldick (2015) defined this term, it is used to refer to events, persons, places, or artistic works without any explanation by the authors, but it can refer to something both authors and readers are assumed to share knowledge of. Lennon (2004) noted that this literary device, especially in newspapers, is elusive; it involves intentionality by the writer and recognition of this intention by the reader depending on reading background, interests and experience. In other words, readers should have some background knowledge relevant to the indirect reference intentionally provided by the writer in order to get the actual message. However, this is not always an easy task for readers. This possible difficulty might be a factor affecting the popularity of using this device in the news headlines.

Furthermore, the infrequent use of metaphor found in this study might be caused by the specific category of the topic. According to Shams (2013), metaphors in newspapers are commonly used in politics and economic news discourse. He further added that metaphor is a tool to create specific effects, to distort the reality, and to slant the news against one side, or a group of people. As supported by Olimat (2020), this rhetorical element is one of the most powerful and persuasive devices used by politicians in discourse and is also a noticeable trait of political rhetoric. He added that the politicians' uses of figurative language can establish the intended attitudes of the people and impact their opinions. However, addressing speeches by politicians differs from presenting news events. The case of COVID-19 has affected people's lives both directly and indirectly throughout the world. During the pandemic, reporting the facts of disease-related storiesthrough media discourse is essential. Newspapers should be a trusted community resource which provides crucial information to the readers. Accordingly, the death toll or the number of new cases of infection has been objectively related to the public. Therefore, information about the disease should be presented using other forms of rhetoric.

\section{COMBINING RHETORICAL DEVICES IN PRESENTING NEWS HEADLINES}

Based on the findings, alliteration and metonymy were the top two rhetorical devices. Although these two rhetorical features fall under different main categories, schemes and tropes, the combination of these sound and meaning-based devicesis a common technique in writing news headlines. In a single headline, the shared devices of alliteration and metonym are often employed to affect the intended meanings and arrange words to emphasise sound effects at the same time. The combination of these rhetorical devices is found in the following headlines: 'Singapore expands quarantine rules for all returning residents' (Bangkok Post), 'France records highest virus daily death toll' $(B B C)$, and 'Israel to impose Passover closure and curfew' $(B B C)$.

Moreover, alliteration and rhyme, which are under the same category of schemes, were also employed together in news headlines, for example, 'Australian liner facing growing coronavirus crisis off Uruguay' (Bangkok Post), 'The teenagers still learning during lockdown' $(B B C)$, and 'Italian union urges pay deal for lower league players' (Bangkok Post). According to Shams (2013), rhyme and alliteration are common phonological based techniques used in news headlines to attract readers and involve them in news stories. Also, Picello (2018) pointed out that these two devices are often employed in advertising to make a product memorable. Certain intended words are arranged and formed through the use of phonological tools to 
enhance the memory of readers. As supported by Shams (2013), apart from the purposes of summarizing the whole news story and beautifying the newspaper page, advertising news reports through the catchy presentation of headlines is another major aim of the media, and good headlines are excellent advertisements for the stories.

\section{SUB-CATEGORIES OF RHETORICAL DEVICES}

To illustrate the rhetorical devices found in this current study, the researcher provides examples of each feature according to the two main categories, schemes and tropes, based on Leigh's taxonomy (1994) cited in Monsefi\&Mahadi (2017).

Schemes relate to syntax, word order, word omissions and insertions, letters, and sounds rather than the meaning of words.

Alliteration is one of the rhetorical features belonging to schemes. The following headlines show the repetition of the initial letters as examples of alliteration.

Examples: $\quad$ Spanish virus deaths toll falls for fourth day $(B B C)$

Drone pictures show bodies being buried $(B B C)$

Beer-drinking mayor fined for flouting virus rules $(B B C)$

Pain, solitude, fear: stories of surviving Covid-19 (Bangkok Post)

Virus spread slows in Malaysia but steady in Indonesia, Philippines (Bangkok Post)

OPEC 'close' to deal on output cuts to counter price collapse (Bangkok Post)

Furthermore, there are often two similar pairs of initial letters in headlines, such as 'South Sudan records first coronavirus case' $(B B C)$, 'What workplaces will look like after lockdowns' (Bangkok Post), 'Kyrgios delivers on food pledge for people going hungry' (Bangkok Post), 'Spain deaths slow, Singapore quarantines dorms: Virus update' (Bangkok Post), etc.

Rhyme, which relates to the final sound of words, is another property representing the category of schemes. The spelling may differ between two or three words in the rhyming pattern, but they still embody the phonological characteristics of rhyme. The presentation of rhyme in the selected headlines are shown in the following examples.

Examples: Australian liner facing growing coronavirus crisis off Uruguay

(Bangkok Post)

New York governor says worst of pandemic 'is over' (Bangkok Post)

Palestinian, Syrian refugees in Lebanon camps brace for virus (Bangkok Post)

Backpacker 'so happy' to return home to family $(B B C)$

Bolsonaro fires health minister over coronavirus $(B B C)$

Coronavirus: Khartoum governor sacked in prayer ban row $(B B C)$

Also, the repetition of this rhetorical device three times instead of twice is found within some headlines, such as 'Top US doctor shows reporter his inhaler' $(B B C)$, and 'Warning for clinics secretly treating wealthy Nigerians' $(B B C)$.

Tropes, unlike the schemes, are another type of wordplay presentation which can change the typical meaning of words through comparison, connotation and word choices by using language in an unusual way.

Metonymy is a sub-category of tropes. In this study, it is mostly used to substitute something represented by the names of countries, institutions, companies, and etc.

Examples: $\quad$ Singapore quarantines 20,000 migrant workers $(B B C)$

This example uses the word 'Singapore' to represent the Singaporean government agency which acts to fight the disease outbreak in that country.

Trump warns US 'there will be a lot of death' $(B B C)$

The word 'US' here can refer to Americans; President Donald Trump reminded his people that the coronavirus pandemic will bring a rising number of fatalities in the country. 


\section{US denies hijacking masks in Bangkok (Bangkok Post)}

The word 'US' is associated with the US Embassy in Thailand. This headline came after the accusation by officials in Germany about the 200,000 face masks bound for Germany being confiscated from an airport in Bangkok and diverted to the United States.

Another example can also show the use of metonymy in the headline 'Chinese football agonises over wage cuts in face of coronavirus' (Bangkok Post).

This headline relates the word 'Chinese football' to 'the football players' who were asked to take a pay cut in an attempt to ease the economic stress caused by the coronavirus outbreak.

The last example exhibiting the use of this rhetoric is 'World observing Easter under lockdown (Bangkok Post). The word 'World' here is used to stand for people who celebrate the Easter holiday only from home under the lockdown.

Simile figuratively functions in the form of comparison. This device is quite similar to metaphor; however, the use of 'as' and 'like' clearly expresses the comparative relation of similes contained in the headlines.

Virus hit 'like a bomb' as toll rises in Ecuador's business capital (Bangkok Post)

The 'virus' and 'bomb' are associated in the form of comparison. Both of them can result in negative effects. The word 'like' can help classify the type of rhetoric more clearly.

Metaphor is used to compare two things to each other. The use of the 'verb to be' is normally employed to relate the two things being compared. However, it is often omitted in writing typical headlines.

Example: $\quad$ The families turned into 'zoo animals' by quarantine $(B B C)$

The people, who have been quarantined in their homes, following their country's precautionary measure to prevent the outbreak of COVID-19, feel that their families' privacy have been violated and they compare their present lives to that of animals in a zoo.

Trump says reopening US 'a beautiful puzzle' $(B B C)$

Pandemic a 'perfect storm' for South Asia, World Bank says (Bangkok Post)

The use of 'reopening US' is compared to 'a beautiful puzzle' and the word 'Pandemic' is compared to 'perfect storm'. the truth.

Hyperbolerefers to exaggeration or figure of speech which is impossible to connect to

Example: $\quad$ Coronavirus 'could wipe out Brazil's indigenous people' $(B B C)$

Covid brings tears and spilt milk to Canadian dairy $(B B C)$

'Undocumented virus explosion' sweeps Brazil $(B B C)$

Hunger for 'good news' grows as pandemic woes deepen (Bangkok Post)

These examples use hyperbole and present impossible situations or phenomena which could not happen according to the literal meaning of the statements the news headline writer created.

Depersonalization is used to imply that inanimate things or non-human beings can act like people.

Example: $\quad$ Virus appears to strike men, overweight people harder (Bangkok Post)

'Medibot' to do rounds on Malaysian wards (Bangkok Post)

'Rice ATM' feeds Vietnam's poor amid virus lockdown (Bangkok

Post)

The verbs 'strike', 'do rounds', and 'feed' are all used to describe human qualities, traits, and activities. 
uninteresting.

Example:

\author{
Stay or go? French fly home from Russia amid pandemic (Bangkok \\ Post) \\ Trump sees 'light at end of tunnel' in virus fight $(B B C)$ \\ 'From Russia with love' aid for Serbia $(B B C)$
}

These three examples are characterised in the form of common expressions. The first example represents the two contrastive words 'stay' and 'go'. The second example 'light at the end of the tunnel' is an idiom which means 'something that shows you are nearly at the end of a long and difficult time or situation' (Hornby, 2000, p.776). The last one 'with love' is frequently used as an expression of letter closing to a family member or a close friend.

Allusion is the use of words or expressions commonly referring to some important events, places, or people. There were only two examples of this device in this study.

Example: $\quad$ Virus-hit US girds for 'Pearle Harbor moment' as death toll spikes (Bangkok Post)

The devastating attack on Pearl Harbor, which is a U.S. naval base near Honolulu, Hawaii, claimed many lives. The headline writer aimed to relate the coronavirus death toll in the hardest-hit country at the present time to the loss and tragedy suffered by Americans from this infamous sneak attack.

Example: World faces worst crisis since Great Depression: IMF's Georgieva (Bangkok Post)

The word 'Great Depression' also represents an example of allusion. According to Delahunty\&Dignen (2010, p. 157), this term refers to a prolonged period of economic depression in the United States, Europe, and elsewhere during the 1930s following the Wall Street stock market crash in 1929. They added that it is mentioned in the context of a major economic slump, or widespread unemployment and poverty. The headline writer used this term to allude to the idea that the negative economic effect of the present global pandemic is comparable to a specific situation in the past, i.e., the Great Depression.

Euphemism can show the writers' ability to deal with word choices and select alternate words which can relate somewhat unpleasant meanings in a more polite way. The study of Winita\&Ermanto (2018) claimed that the existence of euphemisms employed in the headlines related to the avoidance of being offensive, not mentioning something hurtful or tragic, or keeping secrets. Some examples of euphemism found in this study are illustrated here.

Example: $\quad$ Police find 17 bodies at US nursing home after trip $(B B C)$

A way to avoid offensive words or ideas in a socially acceptable form is represented in the use of 'bodies' and 'nursing home'. Strazny (2005, p. 307) pointed out that language forms and is formed by society, referring to the conversion of 'old-age homes' to 'nursing home', 'retirement villages' and 'assisted living places' for 'senior citizens' or 'golden agers'. Similarly, writers of tragic news events often refer to dead bodies as simply 'bodies'.

Example: $\quad$ Ethiopia's first lady calls for mercy in gospel song $(B B C)$

The word 'first lady' replace 'the president's wife'. This term shows the social status and the importance of the role of women in a positive way. The word 'wife' implies an equal role as the spouse of a husband, but the word 'first lady' can persuade readers to recognise and accept females as particularly suitable to be of chief importance to the country and the wider society.

Why African Americans are dying at higher rates from COVID 19 (Bangkok Post) 
The word 'African Americans' is listed as a euphemism in the bookHow Not to Say What You Mean: A Dictionary of Euphemisms of Holder (2008, p. 78) and refers to those whose ancestors came from sub-Saharan regions and were not Boers. Lerner (2010) stated that the word African American may be the current preferred term which can place these people on an equal status with all the other racial groups. If this term is considered euphemistic, it may be because describing these people by their skin color is not value-neutral even though it may seem a natural and obvious way to classify them (Cameron, 2012). She added that the use of this term is equivalent to the use of Japanese-American, Asian-American, and ItalianAmerican, which are terms that include people's racial ancestry and their nationality. Agyemang, Bhopal, \&Bruijnzeels (2005)reported that 'African American' is an alternative term to be used to describe a group of people. It has been employed since at least the 1920s and has been the preferred term in America since the 1970s. They further suggested that the term 'Black' should be carefully used.

Another rhetorical approach to be discussed here is pun. The same or similar sound of words, which can be called homonyms and homophones, is used to manifest different meanings.

Example: $\quad$ Cambodia extends entry ban for passengers from six countries (Bangkok Post)

The word 'six' in this headline can cause readers to think of the phonologically related word 'sick', which can also describe the six countries in which many of the citizens are infected with the coronavirus.

\section{A lone man by the Merlion statue in Singapore $(B B C)$}

Grammatically, the word 'alone' and 'lone' cannot be used in the same way. This means the position of the words used in the headline is different. The word 'alone' is a predicative adjective while 'lone' function as an attributive one. The pronunciation of these two adjectives may cause the readers to ponder the difference in their actual meanings.

Virus-hit cruise ship docks as Australia death toll hits 39 (Bangkok Post)

The same spelling and pronunciation of the words 'hit' occurring twice in the above headline can represent the dominant characteristic of homonyms. However, the two words signify different meanings. The first one, often used in the passive form, can be defined as 'to have a bad effect on somebody/something'; this means that some passengers on this cruise ship were infected with the deadly coronavirus. However, the second 'hit' means 'to reach a particular level' (Hornby, 2000, p. 644). This usage means that 39 Australians patients died of COVID-19.

Rhetorical questions can take the form of either WH-questions or Yes-No questions. Getting an answer is not the purpose of this kind of rhetoric.

Example: What impact is Covid-19 having on Middle East conflicts?

(Bangkok Post)

Could virus crisis kill debt-laden US Postal Service? (Bangkok Post)

How do you stay at home if your home is destroyed? $(B B C)$

Is there any evidence for coronavirus lab release idea? $(B B C)$

As suggested by Shames (2013), this device is not used for getting information but to lead the readers into thinking in a specific way the writer wants to emphasise, to draw a conclusion about something, and to affect the readers' emotions. This is a headline writing technique making use of syntactic features of English. 


\section{DIFFERENT IDEOLOGIES IN PRESENTING NEWS OF THE NATIVE AND NON-NATIVE ENGLISH-} SPEAKING COUNTRIES' ONLINE WEBSITES

The frequent use of metonymy in the $B B C$ may show distinctions of preference in news delivery between the two online newspapers. The uses of this rhetorical device may reflect the preferred attitude of presenting the relevant news stories of each news website. Most names of countries were metonymically employed in the news headlines of the two sites. The names of the countries mostly referred to their governments and people. The study shows that the $B B C$ tended to deliver coronavirus-related news in a wider perspective, presenting the information about the coronavirus disease pandemic from throughout the world. The names of the relevant countries, such as Canada, Italy, Turkey, Australia, India, Japan, Brazil, Spain, Somalia, Zimbabwe, America, were included in the headlines. On the other hand, the headlines created by the writers of the Bangkok Post apparently focused on presenting the news information about neighboring countries, or countries of specific import to Thailand, such as Taiwan, Malaysia, Indonesia, Japan, Hong Kong, South Korea, and the United States of America. This can reflect the subjective ideologies of both news organisations, which are directly affected by their different target audiences. It can be assumed that the news of the Bangkok Post mainly focuses on the relevant target readers who are Thai and those in other neighboring areas while the $B B C$, which is a bigger news organisation, serves more worldwide audience. Considering this, the concept of 'newsworthiness' must be taken into consideration. As pointed out by Stephenson (1998), three common characteristics of news are to have an aspect of human interest, to affect people, and to be dramatic. As a result of this, a piece of news which may not affect the readers' lives cannot be labeled 'newsworthy' and may fail to accomplish the goal of news delivery.

Moreover, it can be noted here that metonymy seems to be a main rhetorical device in writing news headlines. Using the names of countries and institutions to refer to something they are associated with is unique and special. Linguistic understanding and background knowledge are thus other important things which enable the audience to receive the correct information in news stories.

\section{LEXICAL USE IN NEWS HEADLINES}

The uses of some rhetorical devices in this study can reflect certain lexical aspects. In presenting the coronavirus-related issue, the words selected to form the news headlines, especially from the website of the $B B C$, sounded dramatic, catchy, and striking. This emotionally stimulates the readers to perceive and experience the effects of the global disease pandemic concurrently. This study reveals that the news headline writers commonly used negative words, such as death, die, hit, combat, fight, crisis, and virus. This effectively draws their audience's attention to the unusual situations caused by the disease outbreak. Furthermore, the rhetorical techniques used for comparing one thing to another in the news headlines could convey the negative results of the pandemic with more impact. The uses of metaphor and hyperbole are exemplified in the headlines 'Coronavirus 'could wipe out Brazil's indigenous people', 'Covid brings tears and spilt milk to Canadian dairy', and 'The families turned into 'zoo animals' by quarantine', etc. The words 'Pearl Harbor' and 'Great Depression' also clearly illustrate the uses of allusion which portray the negative effects of the ongoing pandemic. According to Shostaka\&Gillespieb (2014, p. 278), "Words are good constructions and providers of information, so headline writers use words as an effective tool of communication, making headlines striking and memorable. They may select words that carry an emotional loading and are used to make a headline have the effect of being attentiongetting." Selecting the right words to produce news headlines is thus very important because 
headlines not only provide information about the specific news story but also make the readers understand the particular intention of the writers.

\section{CONCLUSION}

This paper explores the use of rhetoric in 594 news headlines from the websites of one native and one non-native English-speaking country relating to the COVID-19 global pandemic. The results indicate that there were twelve rhetorical elements employed. The two online websites presented similar dominant rhetorical devices in writing news headlines. They were alliteration, metonym, and rhyme. There were no uses of ellipsis or derogation in the headlines of the two newspapers. Allusion and simile were only found in the headlines from the Bangkok Post website but at very low frequencies. The findings also reveal that the combination of more than one rhetorical device in a single headline was a technique the headline writers of both websites often used.

Word choices are very important in writing news headlines because the headlines play a key role in promoting their product, news stories. Certain powerful words are deliberately selected by headline writers to affect the audience's perceptions and feelings. In this study, striking and catchy words selected to produce the news headlines could have an impact on the readers' perception about the negative effects of the coronavirus pandemic. The stylistic devices which are both meaning-based devices and sound devices were used to make the short messages of news more interesting. Also, the frequent metonymic use, especially in the headlines from the websites of the native English-speaking country, reveal the different ideologies of presenting news between the two online websites.

Further research might focus on the textual analysis of other genres of news stories. Furthermore, other forms of writing and speaking, such as campaign slogans for advertising, famous speeches, and presidential debates would offer insight into other discourse conventions which could enhance the understanding of language use.

\section{REFERENCES}

Agyemang, C., Bhopal, R. \& Bruijnzeels, M. (2005). Negro, Black, Black African, African Caribbean, African American or what? Labelling African Origin Populations in the Health Arena in the $21^{\text {st } C e n t u r y . ~} J$ Epidemiol Community Health. 59, 1014-1018.

Baldick, C. (2015). The Oxford dictionary of literary terms $\left(4^{\text {th }}\right.$ ed). Oxford: Oxford University Press.

Bonyadi, A. \& Samuel, M. (2012). Headlines in Newspaper Editorials: A ContrastiveStudy. International Research Journal of Social Sciences. 1(3), 1-7.

Bowden, M. (2013). How to present: The ultimateguide to presenting your ideas and influencingpeopleusing techniques that actuallywork. Milton QLD: John Wiley\& Sons.

Cameron, D. (2012). Verbal hygiene. New York: Routledge.

Conboy, M. (2007). The language of the news. New York: Routledge.

Delahunty, A. \&Dignen, S. (2010). Oxford dictionary of reference \& allusion ( $\left.3^{\text {rd }} \mathrm{ed}\right)$. Oxford: Oxford University Press.

Farrokhi, F.,\&Nazemi, S. (2015). The Rhetoric of Newspaper Editorials. International Journal on Studies in English Language and Linguistic (IJSELL.). 3(2),155-161.

Harris, R.A. (2003). Writing with clarity and style: A guide to rhetorical devices for contemporary writers. New York: Routledge.

Holder, R.W. (2008). How not to say what youmean: A dictionary of euphemisms (4th ed). Oxford; New York: Oxford University Press.

Hornby, A. S. (2000). Oxford advanced learner's dictionary $\left(6^{\text {th }}\right.$ ed). Oxford: Oxford University Press.

Lamichhane, M. (2017). The stylistic features of newspaper headlines: A case of English dailies. Master thesis, Tribhuvan University, Nepal.

Lennon, P. (2004). Allusion in the press: An applied linguistic study. Berlin: Walter de Gruyter.

Lerner, L. (2010). You can't say that! English usage today. Cambridge: Cambridge University Press. 
Magtira, J.,\& Bernardo, Alejandro. (2017). A Contrastive Analysis of Filipino and American Newspaper Editorial Headlines. Asian Journal of English Studies (AJELS).5, 15-32.

Maretha, A. L. \& Kongthai, A. (2017). The Use of Verbal Rhetorical Devices to Construct Readers' Ideology in Online News Headlines. Paper presented the 5th ASIAN Academic Society International Conference (AASIC). Thailand: Mae Fah Luang University, July.

McGuigan, B. (2007). Rhetorical devices: A handbook and activities for student writers. Clayton: Prestwick House, Inc.

Monsefi, R. \& Mahadi, T. (2016). Wordplay in English Online News Headlines. Advances in Language and Literary Studies. 7(2), 68-75.

(2017). The Rhetoric of Persian News Headlines: A Case Study of Euronews. International Journal of Applied Linguistics \& English Literature. 6(2),36-45.

Olimat, S. N. (2020). Words as Powerful Weapons: Dysphemism in Trump's Covid-19 Speeches.3L: The Southeast Asian Journal of English Language Studies,26(3), 17-29.

Picello, R. (2018). Key concepts of English language and linguistics: A coursebook for university students. Padova: Libreriauniversitaria.it Edizioni.

Reah, D. (2002). The language of newspapers ( $\left.2^{\text {nd }} \mathrm{ed}\right)$. London: Routledge.

Saxena, S. (2004). Breaking news: The craft and technology of online journalism. Delhi: TataMcGraw-Hill Publishing Company Limited.

Shams, M. R. (2013). Newspapers in the ELT classroom: A guide to the English newspaper for ESL/EFL students. Bloomington: Author House.

Shostaka, G.,\&Gillespie, D. (2014). Communicative Tactics of Creating Headlines in British Newspapers. Procedia-Social and Behavioral Sciences, 154, 276-279.

Stephenson, D. (1998). How to succeed in newspaper journalism. London: Kogan Page.

Strazny, P. (2005). Encyclopedia of linguistics. New York: Fitzroy Dearborn.

Tan, K.H., Woods, P., Azman, H., Abdullah, I. H., Hashim, R. S., Rahim, H. A., Idrus, M. M., Said, N. E. M., Lew, R., \&Kosem, I. (2020). Covid-19 insights and linguistic methods.3L: The Southeast Asian Journal of English Language Studies. 26(2), 1-23. http://doi.org/10.17576/3L-2020-2602-01

van Dijk, T. (1988). News analysis: Case studies of international and nationalnews in the press. New Jersey: Lawrence Erlbaum Associates.

Winita, S. \&Ermanto, E. (2019). Euphemisms in the Headlines of HaluanNewspaper.Advancesin Social Science, Education and Humanities Research, 301, 506-512. https://doi.org/10.2991/icla-18.2019.82

Zhou, Y. (2017). An Analysis of Rhetorical Devices in English News Headlines from Thai NewsMedia. Paper presented the RSU International Research Conference 2017. Thailand: Rangsit University, April. 